Fecha de recepción: septiembre 2013

Fecha de aceptación: abril 2014

Versión final: septiembre 2015

\section{Las fotos sacadas de la ESMA por Victor Basterra en el Museo de Arte y Memoria de La Plata: el lugar de la imagen en los trabajos de la memoria de la última dictadura militar argentina. Un estudio de caso}

Florencia Larralde Armas *

Resumen: Rostros, fotos sacadas de la ESMA fue el título que llevó la muestra montada por el Museo de Arte y Memoria (MAM) de La Plata, en marzo de 2007. Se trató de una exposición de las fotografías rescatadas por Victor Basterra del centro clandestino de detención donde estuvo por más de cuatro años, secuestrado y forzado a realizar trabajo esclavo durante la última dictadura militar en Argentina. Estas imágenes, fueron mostradas por primera vez en un espacio de exhibición memorial y artístico, en esa ocasión. En este artículo indagaremos cómo estas imágenes ingresan a un espacio que admite que su lenguaje es el arte. Reflexionaremos sobre los desplazamientos, operaciones de edición y montaje a las que estas imágenes fueron sometidas por parte del MAM. Esta muestra nos interpela a preguntarnos sobre tensiones inherentes a la imagen fotográfica; ya que se encuentran entre la pérdida y la conservación; el registro y la evocación, lo documental y lo artístico; la información y la emoción, el pasado y el presente.

Palabras clave: argentina - arte - centro clandestino de detención - curaduría - desplazamientos - dictadura - documento - fotografía - memoria - museo.

[Resúmenes en inglés y portugués en la página 102]

${ }^{(*)}$ Licenciada en Comunicación Social y Doctoranda en Ciencias Sociales por la Universidad Nacional de La Plata (UNLP). Becaria de Posgrado del CONICET. Actualmente realiza su tesis de maestría, titulada "Fotografía artística contemporánea y memorias de la última dictadura militar argentina: el Museo de Arte y Memoria de La Plata" (Maestría en Historia y Memoria, UNLP), bajo la dirección de Dra. Claudia Feld y Co-dirección de Dra. Silvia Solas.

Rostros, fotos sacadas de la ESMA fue el título que llevó la muestra montada por el Museo de Arte y Memoria (MAM) de La Plata, en marzo de 2007. Se trató de una exposición de las fotografías rescatadas por Victor Basterra del centro clandestino de detención donde estuvo por más de cuatro años, secuestrado y forzado a realizar trabajo esclavo durante la última dictadura militar en Argentina. Estas imágenes, fueron mostradas por primera vez en un espacio de exhibición memorial y artístico, en esa ocasión. Es importante plantearnos aquí cómo estas imágenes, imágenes "sin arte"2, como las definiría Francois Soulages, ingresan a un espacio que admite que su lenguaje es el arte. Es por eso que nos 
parece necesario pensar en los desplazamientos, operaciones de edición y montaje a las que estas imágenes fueron sometidas por parte del MAM. Esta muestra nos interpela a preguntarnos sobre tensiones inherentes a la imagen fotográfica; ya que se encuentran entre la pérdida y la conservación; el registro y la evocación, lo documental y lo artístico; la información y la emoción, el pasado y el presente.

Poco se ha hablado de estas fotografías en el ámbito académico, solo Luis Ignacio García y Ana Longoni se han atrevido a pensar y reflexionar sobre el lugar de estas imágenes en lo que ellos definen como una "memoria visual de la última dictadura argentina" (García y Longoni, 2012 en Revista Sala Grumo, p. 16). En un ensayo recientemente publicado en la revista brasileña Sala Grumo, los autores exponen una tesis que habla de una aparente invisibilización de esas imágenes, cuya base es la idea de que existe una noción común en los estudios sobre imagen, memoria e historia reciente en Argentina bajo el postulado de que "carecemos de imágenes del horror". Los autores analizan las fotos extraídas por Basterra; en su trabajo reconstruyen el corpus de imágenes y sus trayectorias en el espacio público, y se preguntan “¿Porqué no han sido visibles estas imágenes, a pesar de estar disponibles a la mirada pública desde hace décadas?", ya que estas imágenes son públicas desde que Victor Basterra las llevó y dio su testimonio primero a la CONADEP en mayo de 1984, y luego al CELS el 17 de octubre del mismo año (CELS, 1984). Y también en agosto de 1984 fueron publicadas en la Revista La Voz de la Juventud Peronista, regional 1(1984, pp. 11-15). Escapa de nuestro análisis determinar si estas fotografías han sido invisibilizadas, lo cierto es que en el año 2007 el MAM realizó un primer esfuerzo por mostrar estas imágenes, cuestión que no fue analizada ni expuesta por los autores anteriormente citados. Coincidimos en que estas fotografías necesitan aún de una mirada atenta y crítica de lo que exhiben, por eso nos preguntamos aquí, ¿Cómo fueron mostradas estas imágenes? ¿Qué queda visible y oculto? ¿Qué nociones sustentan el armado? ¿Qué sentidos son elaborados y cuáles quedan por trabajar? ¿Cómo estas imágenes ingresan del dominio del sin-arte al arte?

\section{La historia de las fotos}

Víctor Basterra fue secuestrado junto a su esposa y su hija de dos meses, el 10 de agosto de 1979; los tres fueron llevados al centro clandestino de detención de la Escuela de Mecánica de la Armada (ESMA), que funcionaba en un predio de la Capital Federal Argentina. Allí fueron puestos en cautiverio y torturados; la esposa y la niña fueron liberadas a los 5 días, pero él estuvo detenido-desaparecido hasta terminada la dictadura. Luego de su liberación en 1983, y ya en democracia fue vigilado y perseguido por sus secuestradores hasta agosto de 1984.

Al momento de su secuestro, Víctor era obrero gráfico y militante de las Fuerzas Armadas Peronistas (FAP), por eso dada su condición de gráfico y fotógrafo fue puesto a trabajar, como mano de obra esclava, en el laboratorio fotográfico que funcionaba en el Centro de Documentación instalado en la ESMA. Allí se falsificaban pasaportes, documentos de identidad, carnets, escrituras, etc. para el grupo de tareas; por eso Víctor fue puesto a realizar las fotos carnets de los represores, utilizadas en ese tipo de documentación. Estuvo 
obligado a realizar esa tarea esta el momento de su liberación porque no había quien lo reemplace (Museo de Arte y Memoria, La Plata, 2007).

A partir de 1980, y cuando su vigilancia se había ablandado un poco, comenzó a esconder y recolectar imágenes de los represores que fotografiaba; imágenes que sacaría a riesgo de su propia vida. Esta recolección, fue posible debido a que Víctor comenzó a sacar 5 fotos carnets en vez de 4, como le pedían los represores para su documentación; la imagen sobrante era escondida dentro del sobre que contenía el papel fotosensible, es por eso que no fue descubierta, pese a las innumerables requisas que realizaban a su laboratorio, debido a que abrir ese sobre a la luz implicaba velar el papel fotográfico (información recolectada en visitas guiadas al ex-Centro Clandestino de Detención de la ESMA, marzo 2012). Poco a poco las fue sacando escondidas en su ropa interior, durante el último tiempo de su cautiverio que le permitían algunas salidas para visitar a su familia. Siempre tenía que volver porque estaba amenazado, pero esas salidas a la calle permitieron sacar de la ESMA las fotos que había tomado de los represores. También, logró recuperar imágenes de sus compañeros desaparecidos; como el mismo explica

un día, trabajando en el laboratorio, ví que tenían una pila de fotos para quemar, era ya el 83', viste, ya se venían los cambios. Y entre ellas vi mi retrato, mi propia foto cuando me acababan de chupar, la que sacaron el mismo día en que nos fotografiaron a todos contra la misma pared. Entonces metí la mano en la pila, y me guardé los negativos que pude agarrar, los escondí entre la panza y el pantalón, ahí los puse, cerca de los huevos (Brodsky, 2005, p. 31).

Extraer estas imágenes de la ESMA fue un acto de resistencia ${ }^{3}$ que ha servido para testimoniar sobre lo sucedido en la ESMA, para enjuiciar y reconocer a muchos de los represores que allí secuestraron, torturaron y asesinaron. Son fotografías que sirvieron de evidencia, y que analizaremos exhaustivamente más adelante. Durante el año 1984, Victor llevó esas imágenes a la CONADEP, y luego al CELS, en octubre del mismo año. Y logró su publicación en la Revista de la Juventud Peronista.

Esas fotografías fueron utilizadas como prueba judicial en el Juicio a las Juntas en 1985 y en otras causas que investigan los crímenes del terrorismo de Estado, como la causa a Alfredo Astiz y Jorge "Tigre” Acosta, durante la reapertura de los juicios que se llevan a cabo desde el año 2007 y que continúan desarrollándose a la fecha ${ }^{4}$.

En el año 2005, fueron publicadas una selección de esas imágenes en el libro Memoria en construcción de Marcelo Brodsky. Allí en formato libro por primera vez, aparecen tras varias páginas en negro una serie de retratos. De frente, de pie y mirando a la cámara, en formato blanco y negro, tras un fondo negro, aparecen los rostros de los desaparecidos. No así las caras de los represores que no fueron publicadas en este formato.

"Desde entonces (desde la vuelta a la democracia) lleva bajo el brazo una carpeta con las fotos como una ayuda permanente" (Instituto Espacio para La Memoria, s/f, p. 1), según Basterra "Ver las fotos es preguntarnos qué nos pasó en la vida, son un pedacito de nuestra historia" (Instituto Espacio para La Memoria, s/f, p. 1); y con esta carpeta, portando las fotos originales que había sacado de la ESMA, llegó al MAM a fines del año 2006. Como 
explica la actual directora del museo, hubo un doble interés que hizo que convergiera en ese espacio de exposición; por un lado el MAM tenía presente las fotos debido a que tomaron notoriedad al salir publicadas en el libro, y deseaba exponerlas; y por el otro Victor Basterra llegó al MAM de la mano del fotógrafo Marcelo Brodsky que ya había expuesto en el año 2002 (Fuente: Entrevista a Laura Ponicio, actual Directora del MAM, 27 de abril de 2012. Y Paula Bonomi, empleada del área de comunicación y prensa de la CPM, 7 de mayo de 2012). Es por eso que junto a un equipo de curadoras pensaron cómo mostrar esas imágenes, en una muestra fotográfica que se adaptara al perfil de un museo de arte y memoria.

Entre el conjunto de imágenes rescatadas por Basterra se distinguen tres grupos -como analizan García y Longoni-. El primero, se trata de un centenar de retratos de los represores, fotografiados por Víctor. Otro gran grupo de fotos de los desaparecidos que fueron rescatadas de un tacho de basura de la ESMA, momentos antes de ser quemadas. Y un último y reducido grupo de imágenes del edificio y de algunas oficinas de la ESMA, estas fueron tomadas adrede por Basterra y sus compañeros de cautiverio Daniel Merialdo y Carlos Muñoz, con la clara intención de construir pruebas de lo sucedido; algunas de ellas fueron publicadas en Memoria en Construcción (Brodsky, 2005, pp. 96-97), en los pies de páginas se lee por ejemplo,

el playón de estacionamiento del Casino de Oficiales de la ESMA, con algunos Ford Falcon operativos y la camioneta SWAT al fondo. Esa camioneta era utilizada para pasear a los detenidos por la ciudad, para que señalaran otros militantes por la calle. En el mismo playón se estacionaban los camiones que se llevaban a los detenidos para su ejecución (Op. Cit. Brodsky, p. 96).

y “(...) éste es el aspecto que tenía cuando fue fotografiado por Victor Basterra en 1982, mientras 'probaba' un flash” (Id. Ibid. Brodsky, p. 97), se tratan de imágenes que muestran retazos, fragmentos de esa realidad, son instantes que muestran algo de la verdad. Es interesante pensar estas imágenes de acuerdo a la categoría de fragmento, tan desarrollada por Didi- Huberman (2004), porque nos ayuda a pensar en esas fotografías como una materialidad que si bien no muestra el todo de los sucedido, si son capaces de mostrar algo. Trataremos de ver qué nos muestran y cuál ha sido su tratamiento en el MAM.

En la muestra organizada en el MAM solo se utilizaron fotografías de los dos primeros grupos, es decir, de los represores y de los desaparecidos, y se hizo un fuerte hincapié en el montaje. 


\section{El museo}

El Museo de Arte y Memoria de la ciudad de La Plata fue fundado en el año 2002, por la Comisión Provincial por la Memoria (CPM).

El proyecto surge de la necesidad de pensar al arte como un vehículo de transmisión, para pensar todos los temas y problemáticas sociales que trata la CPM. Y ver que hay y que hubo una producción artística, donde uno puede abordar y transmitir ideas, sobre todo los temas más vinculados al horror y al pasado reciente, para poder pensar con las nuevas generaciones. $\mathrm{Y}$ el arte en ese sentido es un canal maravilloso porque no paraliza, sensibiliza y amplia fundamentalmente el círculo de los convencidos (...) entonces surge por esa necesidad de poder pensar la transmisión de la memoria (Fuente propia, 7 de mayo de 2012).

Es así que entre los objetivos del museo se encuentran el de generar un espacio de sensibilización y transmisión de la memoria colectiva a través del arte. También tienen un fuerte trabajo con las nuevas generaciones, que es canalizado por medio de visitas guiadas a escuelas secundarias y un trabajo de extensión cultural con muestras itinerantes, de la que es parte la muestra Rostros. Fotos sacadas de la ESMA.

Desde su fundación y hasta el año 2012 el MAM estuvo bajo la dirección de Ana Cacopardo; durante su gestión se expusieron muestras artísticas de diferentes disciplinas como plástica, fotografía, teatro, cerámica y cine; y muestras de producción propia de la CPM, donde por ejemplo se exhiben contenidos del archivo de la DIPBA (Dirección de Inteligencia de la Policía de la Provincia de Buenos Aires), estos trabajos han sido realizados en conjunto con el MAM, muchas veces a cargo de la fotógrafa Helen Zout y con un montaje de carácter artístico. El museo hace desde su fundación una muestra de elaboración propia todos los años. Es por eso que ya tienen experiencia no solo en la exposición y curaduría, sino también en la creación de muestras y objetos artísticos. Cuestión que permite entender algo del lugar que tomó el MAM a la hora de pensar la muestra, ya que, como han explicitado las curadoras, hubo una creación de la obra a partir de las fotos. Hubo una puesta en escena, montaje, edición de las imágenes y hasta la creación de una instalación audiovisual. "El arte en nosotros está en otro lado, en cómo lo mostrás" (Fuente propia, 27 de abril de 2012), es decir que aquí el arte no solo está en las piezas, sino también en las formas de montaje.

Entre las características que tienen las instituciones museísticas a lo largo de su historia, se cuenta la de poseer un horizonte de expectativas prevaleciente en su público (Edwards, 2006, p. 251), es decir que existe una "colaboración tácita entre los conservadores y el público para mantener una expectativa" (Edwards en Naranjo, 2006, p. 253) de lo que va a encontrar un visitante al ingresar a un museo, sea del tipo que sea. Por lo que al tratarse de un Museo de "Arte" y "Memoria", el nivel de expectativas no solo se amplía sino que se complejiza, requeriría de un estudio de recepción poder vislumbrar fehacientemente la perspectiva del visitante que llega al MAM, pero lo cierto es que esta relación entre arte y memoria dentro de este espacio aún es objeto de amplias reflexiones y debates. 


\section{Las fotos. Sacadas "DE" la ESMA}

Como hemos explicado más arriba las fotos rescatadas por Victor Basterra son públicas desde que las llevó al CELS en 1984, desde el Juicio a las Juntas han circulado por juzgados, en periódicos y en internet, y fueron publicadas en el diario del juicio. En el año 2005, algunas de las fotos de los desaparecidos, fueron publicadas en el libro "Memoria en Construcción", cada una de ellas ocupaba una página, sobre un fondo negro. Se seleccionaron para esta publicación solo las imágenes en que los detenidos están de frente, mantuvieron el encuadre original, es decir, el plano completo hasta los pies, y algunas en $3 / 4$ hasta la rodilla. Cuestión que no se mantuvo en la publicación del CELS donde casi todas las fotos fueron cortadas, generando un reencuadre del tipo foto carnet. En la Revista de la JP se publicaron los tres grupos de imágenes, con recortes diferentes. El MAM realizó otro tipo de recortes, diferentes a los del CELS y a los de la Revista de la JP, a continuación los analizaremos más puntualmente.

Fancois Soulages reconoce dos grandes grupos de fotografías, las "sin-arte" y las artísticas, y la característica primordial que las diferencia es la voluntad del fotógrafo a la hora de tomarlas, es decir, si en el momento de toma había o no una intención u objetivo artísticos, un proyecto, o una pretensión artísticas. Obviamente las fotos de Basterra no fueron tomadas con intención artística; pero otras de las cuestiones que suceden con la imagen fotográfica es que ella no es algo estático, por lo que se dan movimientos que permiten que imágenes "sin- arte" de pronto puedan ser consideradas arte, y viceversa. Entonces es posible preguntarse por esta transformación, imágenes que eran documentos y hasta prueba judicial de pronto se encuentran exhibidas artísticamente, ¿qué pasó en el medio? ¿Cómo se dio este desplazamiento?

Las curadoras de la muestra relatan que las fotografías de los desaparecidos las scanearon del libro de Brodsky porque Victor no las tenía. Y con respecto a las de los represores ambas cuentan que se reunieron con Basterra que tenía los originales y junto a él realizaron la sistematización de ese material, es decir, lo escanearon en alta calidad, para poder hacer copias de mayor tamaño. Con Laura Ponicio realizaron la tarea de ponerle nombre a cada uno de los rostros de los represores, "no tenía bien el nombre de cada uno de ellos, tenía los sobrenombres de cómo se llamaban ahí (en la ESMA), asique me trajo un sobrecito, con todas las fotos y yo iba agarrando una foto y la pegaba sobre una hoja y él me iba diciendo los nombres de cada uno" comenta. Y es que tal cual explica Bonomi, "construimos con él ese material”. Esto es algo interesante que marca más interrogantes que certezas ante la pregunta de porqué no utilizaron la información de la Publicación del CELS, y volvieron a hacerlo, cuando 23 años antes ya se había realizado esa tarea. Juntos volvieron a nominar los rostros a ponerle nombre y apellido, tal vez como un nuevo acto de rememorización para ambos, como otro acto de memoria para Basterra y Ponicio. La cuestión es que finalmente en los rótulos los datos aparecen idénticos que los del informe del CELS. Victor vuelve a contar esta historia, testimonio que ha repetido desde la primera vez que hizo su declaración para la CONADEP, a la Revista de la JP tanto como al CELS, y luego en los juicios. Actualmente suele ir a la inauguración de la muestra, que fue reeditada por el Instituto Espacio para la Memoria, y que es instalada en distintos puntos del país, y en cada presentación vuelve a dar su testimonio (estas imágenes se han mostrado en el 
Centro Cultural Recoleta en octubre de 2007, en la Comisión Provincial por la Memoria de Chaco en marzo de 2008, en La Rioja marzo de 2008, en Trelew en junio 2009, en San Rafael en agosto 2010, en Lanús en diciembre de 2011, entre otros).

Aquí, hubo una primer tarea, la de construir el archivo, de reunir, y transformar esos documentos en un conjunto definido. De diferenciar los dos grupos, rastrear las imágenes faltantes y producirlos a nivel visual, escanear el conjunto y cambiar su tamaño. El MAM junto con Basterra tuvo la tarea de producir esos documentos, y de esta manera cambiaron el estatus y lugar de esa materialidad, y pasan de ser vistas solo como un documento histórico probatorio de causa judicial, a objetos plausibles de mostrarse en una muestra artística, ya que como nos explicaba Laura Ponicio "el lenguaje del museo es el arte" y es con ese objetivo que se trabajó sobre ese material.

El arte en este tipo de fotografías se enfrenta a ideas disímiles, por un lado Hubert Damisch "la fotografía tiene una pretensión artística cada vez que cuestiona, en la práctica, su esencia y sus funciones históricas y cada vez que revela, manifiesta su carácter contingente" (Damisch, 2007, p. 11), para Damish la fotografía es artística cuando la imagen no es confundida con su referente. En el caso de las fotografías rescatadas por Basterra su potencial y fuerza justamente recae en su poder referencial. Y por el otro Jean-Claude Lemagny propone entender a la fotografía como arte por su directa conexión con el misterio y la imaginación, es decir, por un lado se trata de una huella de lo real, pero el significado de esa huella nunca es acabado, ya que "en su soledad, cada foto, desconectada de la red de relaciones por la cual damos sentido a las cosas, nunca significa nada" (Lemagny, 2008, p. 72), es decir que es el contexto de enunciación, en este caso el construido por el museo, el que traza su significado y le otorga el status de arte. Y es que como sostiene Elizabeth Edwards en todos los museos las técnicas de enunciación desempeñan un papel fundamental, que en este caso no solo apuntará a la exhibición del material fotográfico como tal sino también a un acto de visión reflexivo se ese material.

\section{Las fotos}

Reconocemos el lugar de ratificación o construcción de una verdad por parte de las fotografías expuestas, y es esa una de las intenciones explícitas por parte del museo. Son imágenes que tienen el valor de prueba, que nos especifican que esas personas estuvieron dentro de la ESMA, algunos como detenidos y otros como represores. Pero al analizar las fotografías en tanto materialidad, observamos que si bien su uso recae en su valor referencial, la certificación del contexto al que pertenecen recae en el testimonio que da Basterra (Feld, 2012). Las imágenes, en sí mismas y por tener esa característica, tan analizada por Didi- Huberman, de ser fragmentarias, de poseer lagunas, de ser incompletas y no mostrar todo lo sucedido, en este caso en la ESMA, muestran retazos, trozos dentro del contínuum de lo que fue ese centro clandestino de detención, son imágenes que pese a todo, nos muestran instantes de esa realidad; y que nos permiten en tanto espectadores imaginar y completar esa información con otras fuentes de las que disponemos, como testimonios o libros 3 . Edwards dice que es una posibilidad que otorga la fotografía, al tratarse de "un 
relato inacabado que puede utilizarse en el espacio del museo para ampliar una autoridad cerrada y posicionar al sujeto-espectador en la construcción colectiva del conocimiento" (Op. Cit. Edwards, p. 264). En este sentido el autor sostiene que "Museos de la memoria", como los que conmemoran e informan sobre el Holocausto, también tienen estrategias fotográficas muy claras, vinculadas a experiencias históricas concretas, en las que la certeza técnica de la huella fotográfica es fundamental para los propósitos del museo" (Id. Ibid. Edwards, p. 258). Laura Ponicio nos explica que "son temas difíciles de mostrar, pero a la vez tiene que quedar recontra certificado que eso pasó (...) y eso te lo permite la fotografía", y es entonces que el valor de esas fotografías recae en su carácter indicial, aunque el testimonio sea el que nos da la mayor cantidad de información sobre la historia de esas fotos y sobre lo que muestran. "La fotografía es la momificación del referente. El referente se encuentra ahí, pero en un tiempo que no le es propio" (Barthes, 1994, p. 24) dice Roland Barthes y es juntamente eso lo que sucede en el museo, y por lo que tiene tal valor, se está contando una historia de la no puede quedar dudas de que sucedió. Aquí se da una relación que hace convivir una característica de la fotografía como es su índice de verdad, con la imagen fotográfica como arte. Esta convivencia puede verse en distintas dimensiones que analizaremos a continuación: color, encuadre, e instalación.

\section{Cuestión de climas}

La muestra se organizó en dos grandes sectores, se dividieron las fotografías en dos de las salas de exposición, una de las ideas centrales fue separar y diferenciar marcadamente un grupo del otro. Para eso se tomaron decisiones en cuanto a la estética, como por ejemplo al pasar las fotos de los desaparecidos al color sepia, y mantener la de los represores en blanco y negro, también se optó por pintar las habitaciones de diferentes colores y escribir los nombres de las personas con distintas tipografías.

Las imágenes expuestas en el MAM fueron alteradas en dos niveles, en principio a las fotos de los desaparecidos se le cambió el color, las pasaron del byn al sepia, para que dé una "sensación más cálida", explica la curadora. Al analizar las fotografías, podemos pensar que al cambiar el color, parte del studium ${ }^{5}$ de la imagen se pierde. Y esta manipulación de la imagen, obstruye parte de la verdad histórica del documento, disipando parte de la información contextual de las imágenes. Es decir, que son fotos sacadas de y en la ESMA como negativos, y luego fueron reveladas en ByN por Víctor Basterra en la casa de un amigo. Esta decisión borra un studium, del que las fotografías eran parte, y que fueron reafirmado al haber circulado por medios de comunicación en su formato en ByN, es decir, que aquí parecen imágenes nuevas que nunca antes habían sido mostradas, cuando la realidad es que son imágenes que nunca habían sido mostradas así.

La sensación de calidez se pone a prueba por un error de impresión en el folleto, en el que los colores fueron intercambiados, es decir, los represores están en sepia, y la detenida, de la que solo hay una fotografía en el folleto, en ByN [Ver Figura 3 en Catálogo de Figuras en página 96]. Esta equivocación nos sirve para pensar si verdaderamente sólo el cambio de color puede dar una sensación diferente de un grupo a otro. En sí mismo el color sepia 
remite a un tiempo antiguo en que las fotografías se sacaban en esa tonalidad, a un tiempo más atrás que el de la última dictadura argentina. Además traen la sensación de un documento corroído por el tiempo, está como la idea de degradación del material, más que de una sensación acogedora. Es decir que el cambio de color en realidad genera más una pérdida en la noción del tiempo al que pertenece la imagen que a una sensación emocional.

La impresión cálida se da más por la puesta en escena, que por solo el recurso del color. Ya que la sala con las fotos de los desaparecidos, estaba pintada de un gris verdoso, y las fotografías fueron colgadas desparramadas, como piezas de un rompe cabezas (Fuente propia, Entrevista a María Julia Alba, 23 de abril de 2012). Debajo de cada imagen estaba escrito el nombre de cada persona con tiza, en letra manuscrita, "para que tuviera un trazo más humano" (Id. Ibid. Entrevista a María Julia Alba), explican [Ver Figura 1 en Catálogo de Figuras en página 96], es decir sosteniendo la idea de que es otra persona que con el gesto de trazar el nombre del desaparecido le instala una impronta de personalidad, que es única e irrepetible. Además la iluminación tuvo mucho que ver, las fotos estaban iluminadas por focos de luz amarilla, que deban desde arriba sobre la misma pared en que estaban colgadas las imágenes, y esto colaboraba como recurso a esa sensación.

La sala parece más un homenaje que una muestra testimonial, de denuncia o documental. Se reafirma la idea del título de la muestra, "sacados DE la ESMA", las fotos aparecen sacadas de su contexto, como si descontextualizar la imagen y crear una sensación de cobijo se le diera también cobijo a los retratados. Se pierde el contexto de producción de la foto, cuáles eran las condiciones de esas personas a la hora de la toma. Y a la vez hay algo que queda a medio camino o no se logra a entender, hay algo que se tensiona también, y es la idea de homenaje. Es extraña la idea de homenaje con imágenes tan desdichadas, que si bien muestran los nombres de los detenidos, como una afirmación de su identidad e intenta sacarlos de ese lugar de desaparecido $\mathrm{NN}$, hay una sensación que incomoda. Pero, ¿Por qué incomoda?; incomoda, porque como ha trabajado Ludmila Catela Da Silva (2001), en su análisis sobre las prácticas de los familiares de los desaparecidos el homenaje tiene unas características distintivas: en general estos homenajes son colocados en algún espacio íntimo y diferenciado, como en mesitas de luz o en mesitas en el living, se utilizan imágenes que retraten al desaparecido en una escena feliz, y se utilizan objetos como flores, cartas y velas; estas últimas que dan una iluminación amarillenta que intenta emular el museo con su puesta. Aquí hay ciertos elementos que retoma el museo como la luz, y el trazo a mano, propios del contexto familiar, pero a la vez se utilizan imágenes del después, es decir, de cuando ya han sido secuestrados, imágenes del ámbito público pero montadas de una manera íntima. Y es aquí donde se produce la incomodidad, porque hay un desfasaje. Se utilizan elementos del homenaje, pero con fotos que dan testimonio de un acontecimiento de violencia sobre las víctimas, por eso esta muestra no puede ser leída como una muestra testimonial o documental donde primaría el contar el suceso, más que homenajear a las víctimas.

Las fotografía de los represores fueron puestas en otra sala del museo, se trataron de la típica foto carnet, se muestran rostros conocidos como Alfredo Astiz, Jorge Eduardo Acosta, Rubén Jacinto Chamorro, entre otros, pero la pose asociada a la documentación legal no causa demasiadas emociones, y su vez se dispara algo en la asociación mental de nuestra cultura visual, y es que las fotografías de tipo carnet están íntimamente relacionadas con 
las luchas por la verdad, la memoria y la justicia emprendidas por los familiares de desaparecidos, cuestión analizada por Ludmila Catela da Silva que reconoce el lugar ganado por este tipo de fotografías carnet y en ByN en el espacio público y privado (Catela da Silva, 2009, pp. 337-363), de modo que se da también un desfasaje de relaciones, por un lado son rostros de represores, pero retratados a la manera en que los rostros de los desaparecidos circularon por el ámbito público en las luchas por la justicia por parte de Madres de Plaza de Mayo . Dentro del grupo de imágenes que Basterra llevó al CELS (Op. Cit. publicación del CELS), y que pueden verse en su publicación, hay algunos rostros en los que hay más de una imagen, de los que el MAM seleccionó solo una foto de cada uno, por lo general los fotografiados miran a la cámara y el resto está de 3 /4 perfil, y tienen un gesto inexpresivo, muchos de ellos con el uniforme militar, no se ve el fondo porque el encuadre es muy ceñido, asique no se observan datos sobre el lugar en que fueron tomadas esas fotos. Son imágenes que se utilizaron en documentación falsa por el grupo de tareas de la E.S.M.A., es por eso que muestran escasa información, y tienen un carácter muy homogéneo.

Las imágenes de los represores tuvieron un doble tratamiento, por un lado, se las puso en una sala, colgadas y enmarcadas formando columnas de cuatro fotos cada una, ordenadas como un mosaico, los epígrafes de las fotos fueron hechos a computadora y la sala estaba pintada de blanco, por lo tanto todo allí era en blanco y negro [Ver Figura 2 en Catálogo de Figuras en página 96]. Se organizaron sobre dos paredes, sobre una de ellas se colocaron a los más alto rango, y se imprimieron en un tamaño mayor, de 30 centímetros por 40 . Y los de menos rango en la pared adjunta en un tamaño de 20 por 30 centímetros. Todos los rostros tienen su respectivo pie de foto que especifica nombre, alias, y tareas en la ESMA, información copiada idéntica de la publicación del CELS (Id. Ibid. publicación del CELS). Estos fueron tipeados a computadora, y a diferencia de la otra sala, se percibe la idea de un trazo más sistemático, repetitivo y estático.

A su vez se utilizó una tercer sala, en ella se proyectaba a oscuras las diapositivas de los rostros de los represores sobre una pared, esas diapositivas fueron hechas especialmente por el MAM a partir de las fotos originales que tenía Basterra. En esa sala el sonido era muy importante ya que "el disparador del positivo que generaba el proyector de diapositivas, tiene un ruido muy particular y te da la sensación de otra época y además te coloca en las fotos blanco y negro" (Fuente propia, entrevista a Paula Bonomi, 7 de mayo de 2012). El proyector además también permite una continuidad de la imagen en el tiempo, ya que la exposición de la toma sobre una pared tiene un período de duración para el espectador, tiempo que lo interpela a que él piense o reflexione sobre lo que aparece en la pantalla, cada retrato está intercalado con una toma en blanco que refuerza la idea de denuncia; es decir que en ambas salas se observa una intención de escrache. Entre los objetivos de este montaje aparece el de señalar a los responsables, mostrar los rostros, orientados hacia una condena social; cuestiones que fueron base en la organización y desarrollo de los escraches por parte de la organización H.I.J.O.S y con colaboración de los grupos GAC y Etcétera desde 1996 (Cueto Rúa, 2010, pp. 165-183). "La palabra escrache significa en lunfardo "sacar a la luz lo que está oculto", "develar lo que el poder esconde": que la sociedad convive con asesinos, torturadores y apropiadores de bebés, que hasta aquel momento permanecían en un cómodo anonimato" (Carras, 2009) y es bajo estas ideas que se pensó el montaje de las salas de los represores. 
Con respecto al montaje, puede pensarse también como una instalación, ya que no solo se trata de la disposición de las imágenes fotográficas en el espacio, sino que se le sumaron recursos sonoros y audiovisuales.

María Julia Alba, otra de las curadoras de la muestra, comenta que hubo una gran discusión sobre el cómo montar las fotografías ya que "las fotos no son artísticas, no hay una intención, una composición, se trata, si se quiere de un registro del horror", es por eso que uno de los ejes centrales del museo fue el montaje, ya que el MAM posee esa característica de hacer convivir al arte y al documento en muchas de sus muestras, dado que suele usar archivos de la DIPBA para sus exposiciones, como otra de las formas de difusión y elaboración del acervo fotográfico del que se encarga la Comisión Provincial por la Memoria (Fuente propia, entrevista a Ana Caccopardo, directora del MAM durante el período 2002- 2012, 9 de agosto de 2012).

La muestra estaba precedida por un texto que explicaba quién era Victor Basterra, cómo había obtenido esas imágenes y cuál era el objetivo de mostrarlas; esa descripción fue reproducida en la contratapa del folleto de la muestra, y fue producto de entrevistas que le realizó Paula Bonomi (luego publicada en la Revista Puentes Nº 20, 2007). Entre los objetivos de Basterra se encuentra el de "que ese rostro que aparece ahí, a veces sin nombre, porque en muchos casos es un misterio, aunque sea de casualidad, pueda ser identificado, que alguien diga ipero si este tipo vive a dos cuadras de mi casa!" (Folleto de la muestra Rostros. Fotos sacadas de la ESMA, 2007. Producción del Museo de Arte y Memoria, CPM), cuestión que han elaborado, tratado y militado fuertemente la agrupación H.I.J.O.S fundada en 2005 y cuya militancia ha germinado fuertemente en la ciudad de La Plata.

Se mantiene una intención militante, que fue la que impulsó el rescate de todas esas imágenes, y la que promueve su exposición. Es por eso que, es importante observar y tratar de entender esas imágenes que "pese a todo" (Didi-Huberman, 2004) nos muestran vestigios, retazos fragmentarios, de lo que fue el cautiverio en un centro clandestino de detención en la argentina dictatorial. Estas imágenes tal como sucede con las analizadas por Didi- Huberman muestran jirones de un acontecimiento, no lo logran mostrar por completo, pero lo salvan del olvido. A su vez ambos tipos de imágenes son cargadas, por quienes las rescataron y decidieron que era necesario mostrarlas a la luz, por la confianza en la verdad que ellas muestran. Son fotos que emergieron para ser mostradas, con una fuerte idea del valor testimonial que ellas contienen por sí mismas y que en realidad no se da en su completitud. Pero son esas ellas las que permiten preguntarnos sobre las condiciones en que fueron engendradas estos testimonios fotográficos. A continuación analizaremos qué es lo que alcanzan a mostrar esas imágenes, qué queda aún invisible, qué información nos proporcionan.

\section{Cuestión de encuadres. Cuatro encuadres para una misma foto}

Estas fotografías, al observarlas detenidamente, muestran a los detenidos-desaparecidos con vida dentro de un centro clandestino de detención, pero sufren un segundo nivel de alteración, ya que además de la tonalidad es alterado el encuadre. Y esta es una de las fundamentales características que pone a prueba la idea de referencialidad de la imagen 
fotográfica, "fotografiar es encuadrar, y encuadrar es excluir" sostiene Susan Sontag (1993, p. 57). Ambos grupos de imágenes tienen un encuadre muy ceñido, sobre todo las de los represores que son en formato carnet. Asique no se puede ver nada del lugar de la toma, solo vemos rostros y ahí está la potencialidad de esas imágenes. Comparando las fotos que aparecen en el documento del CELS con las utilizadas en el MAM, en las fotos de los represores observamos un pequeño recorte para que todas las fotos queden iguales, a muchas de ellas se les ha sacado unos centímetros por los costados, recortando algo del hombro. En el caso de las fotos de los desaparecidos se han dado cortes más tajantes y visibles. En principio estas imágenes como las anteriores no contienen casi ninguna información sobre el lugar en donde estaban las personas, todos ellos fueron retratados contra una pared blanca o contra una puerta blanca, donde no se puede ver ningún indicio que indique en qué lugar fueron tomadas. Entre los recortes que observamos se dan tres casos paradigmáticos, el retrato de Sosa, Ida Adad y Alberto Eliseo Donadio. Compararemos en cada caso las fotos publicadas por el CELS, las publicadas en la Revista de la JP, las que aparecen en el libro Memoria en Construcción y las exhibidas por el MAM; ya que en cada caso hubo un recorte distinto.

En el informe del CELS hay tres imágenes de Alberto Eliseo Donadio [Ver Figura 4 en Catálogo de Figuras en página 97], una de cuerpo completo, donde se puede ver que está esposado con los brazos para atrás, otra que es una ampliación y recorte de ésta, aquí se focaliza en el rostro y está recortada a la altura del pecho, y la última es de una foto del rostro de Donadio de perfil. En la publicación de la Revista de la JP [Ver Figura 5 en Catálogo de Figuras en página 97] aparece solo uno de los retratos, Donadio está de frente, con las manos esposadas hacia atrás, la foto solo lo muestra hasta debajo de la cadera, se trata de un recorte de la foto de cuerpo completo que publicó el CELS, la imagen es muy ceñida ya que se le recortaron todos los bordes, y el cuerpo de Donadio ocupa todo el espacio del cuadro. En el libro de Brodsky [Ver Figura 6 en Catálogo de Figuras en página 97] fue publicada la misma foto, pero sin los recortes de alrededor del retratado, se mantiene el encuadre hasta debajo de la cadera; hasta se observa en el borde derecho una rasgadura en el papel evidenciando que estaba pegada en algún libro o registro. En el MAM [Ver Figura 7 en Catálogo de Figuras en página 97] se utilizó ésta misma imagen, solo se le recortó la parte de la rasgadura del papel. En esta selección la publicación de la JP, la libro del Brodsky y la muestra del MAM prescindieron de las imágenes más asociadas al tipo de tomas de prontuario policial e hicieron uso de la imagen en que se lo ve en un plano más abierto, hasta debajo de la cadera, aquí se puede ver además algo de las condiciones en las que estaba, esposado, y con una cara desencajada, huellas que nos permiten imaginar algo de esa situación de encierro y tortura. En el pie de foto de la Revista solo dice "Tres desaparecidos -se ignora su identidad-que pasaron por allí (por la ESMA)", pero para el momento de su publicación en el libro y luego en la muestra ya se conocían los nombres de los retratados. La foto del libro también nos muestra que la imagen pertenece a algún tipo de registro. Según entrevistas a la prensa (Página 12, 20 de noviembre de 2005) esas fotos las fueron a buscar Brodsky y Basterra, al juzgado número 12 donde se estaba tratando la causa ESMA, para la confección del libro; es decir que son los originales sacados de la ESMA.

La toma de Ida Adad presenta otras características: el CELS [Ver Figura 8 en Catálogo de Figuras en página 98] recorta la imagen a la altura del pecho, reeditando con su uso la 
lógica del prontuario policial, aquí se le presta relevancia solo al rostro, de manera que sólo aporta información sobre la identidad de la persona y le resta importancia a otros indicios que se ven en la fotografía y que pueden hablarnos un poco de las condiciones en que se encontraba Ida al momento de la toma. Aquí notamos en principio una utilización un tanto burocrática de la imagen, reconociendo su valor solamente en su carácter de identificación de la persona. En la Revista de la JP [Ver Figura 9 en Catálogo de Figuras en página 98] se publican la foto de frente y de perfil, ambas cortadas por debajo de la rodilla, en el pie de foto se lee "Tía Irene" (también figura así en el CELS), seguramente su apodo en la ESMA, porque en las demás apariciones se la ve con su nombre completo. La imagen en Brodsky [Ver Figura 10 en Catálogo de Figuras en página 98] está completa y vuelve a verse la procedencia a algún tipo de cuaderno por los recortes en los bordes. En ella vemos a una señora encorvada mirando a cámara, y lo más punzante, en términos de Barthes, es el detalle de sus cordones desatados. Otro de los indicios de la situación en la ESMA, como un descuido que subraya su imposibilidad de aseo o prolijidad, el rostro desencajado y cansado, y la pose remarca la idea o sensación de las condiciones en que ella estaba allí. En el MAM [Ver Figura 11 en Catálogo de Figuras en página 98] la foto fue cortada justamente a la altura de los pies, comienzan a verse los zapatos, pero no los cordones, que es uno de los detalles e informaciones que más instiga a pensar sobre la situación de Ida en ese momento. Este borramiento puede responder a la idea de homenaje que se le dio a este montaje, aquí el museo en ese gesto de recortar ese detalle intenta dignificar a la víctima, hay una idea de protección a las víctimas que sobrevuela todo el montaje en la sala de los desaparecidos.

Por último la foto de Sosa nuevamente es recortada por el CELS [Ver Figura 12 en Catálogo de Figuras en página 99] a la altura del pecho. En la revista de la JP [Ver Figura 5 en Catálogo de Figuras en página 97] a la foto solo se le han quitado los bordes, espacio donde se ve algo del fondo y del mobiliario, pero no hubo un reencuadre del retratado. En el Libro de Brodsky [Ver Figura 13 en Catálogo de Figuras en página 99] la imagen está completa; se ve la misma característica en los bordes al igual que en las anteriores fotos, además se observa en el fondo algún tipo de cañería y mobiliario como un banco, y el dato importante es el de las esposas, que muestra parte del accionar militar y de la idea de llevar un registro de los secuestrados, Sosa se ve de frente y sin signos de violencia ni cansancio. En el caso del MAM [Ver Figura 14 en Catálogo de Figuras en página 99] se recortó a la altura de las manos y las esposas ya no se ven. Nuevamente notamos que este recorte recae sobre las ideas de homenaje y protección de las víctimas con que fue trabajado el material. El CELS, la revista de la JP y el MAM editan la foto, de diferentes formatos. El primero intentando que todas respondan al típico cuadro del 4X4, hasta los hombros, típico de los registros legales; restando el valor de huella, prueba o testimonio sobre las condiciones de cautiverio que dejan entreverse en la imagen. Esa información recae en el testimonio de Victor Basterra que antecede la secuencia de fotos de los represores y de los desaparecidos. Los recortes de la JP, (en estos tres casos) puntualizan su publicación en la figura de la persona, recortan los bordes y en algunos casos los reencuadran para que queden en un formato americano (por debajo de la rodilla), aunque en otros de los retratos (que no hemos analizado aquí) se generan otros recortes de difícil homogeneización, los mismos fueron publicados en dos notas, una titulada "El campo por dentro" en la que se ve la foto 
de Sosa, Elsa y Donadio, debajo del relato de un episodio sucedido en cautiverio; las imágenes restantes aparecen debajo del titular "Pruebas a la justicia"; aquí al tratarse de una publicación del tipo periodístico las imágenes entran en estrecha relación con el texto, en el que se hace un fuerte foco en el testimonio de Basterra que cuenta parte del cotidiano de la ESMA, su tarea allí, las condiciones en las que estaban y hasta el relato de un episodio que sucedió para las fechas de Navidad y Fin de Año en el que se muestra como era el trato entre uno y otro grupo, aquí el poder de la imagen es realzado y potenciado por el texto que le da contexto, ubicación y explicación. En cambio en el recorte del MAM no se trata de una edición para que todas las fotos respondan al mismo encuadre sino para no mostrar ciertos datos, como los cordones de las zapatillas de Ida o las esposas de Sosa. Las huellas más contundentes de la violencia sobre los cuerpos son excluidas, y aunque son imágenes que muestran una realidad trágica, intentan mostrar una idea de víctima en la que las pruebas de ese status no se puede ver. La idea de homenaje traza un el efecto de sentido, que necesita del borramiento o la invisibilización de los indicios de la violencia y del lugar de víctima de esas personas. Son imágenes que como en el título de la muestra "sacan" de la ESMA a los retratados, les dan una identidad al escribir los nombres, y tratan de correrlos del lugar de víctimas para pasar a ser objetos de respeto, recuerdo y homenaje.

\section{Interrogantes}

El MAM propone una manera de abordar el material y frente a ese desafío creemos que el museo optó por una exposición un tanto más "amable" con las víctimas, pero a riesgo de perder la historicidad del objeto mostrado. La sensación es que nos muestran los protagonistas de una historia, pero no se nos muestra la historia en sí. Nos muestran dos bandos, de los que el espectador deduce quién es el victimario y quienes las víctimas, pero poco se habla de la realidad vivida en situación de cautiverio de esas personas, los recortes en las imágenes de los desaparecidos son muy tajantes y excluyen información valiosa para comprender esa realidad, las huellas más contundentes de la violencia y disciplinamiento sobre los cuerpos no nos es mostrada. Entendemos que esta separación y el montaje de los tres sectores por parte de MAM fue una decisión no solo estética sino política, ya que interpretamos a estas operaciones como decisiones para un discurso comunicativo para el espectador, donde el mensaje es armado y elaborado institucionalmente, en este caso con un lenguaje artístico. La sala de los desaparecidos tal vez puede ser pensada como una sala- homenaje; mientras que la de los represores parece una sala- escrache, sobre todo la que tiene el proyector, con ese sonido que parece un disparador. Pero en esta decisión la posibilidad de la vinculación entre ambos grupos queda difusa, aquí las imágenes de los desaparecidos nunca pueden ser transformadas en su significación, por la de los represores, no hay posibilidad de reenvíos, ni de diálogos. Porque aquí el montaje coarta la interrelación entre los diferentes grupos de imágenes 6 . 
La pregunta es ¿cómo mostrar esas imágenes gestadas en tan compleja realidad? Nos coloca en el incómodo lugar de problematizar la historicidad de los objetos que son mostrados, y del valor del documento como tal, debido a que el agregado y edición artístico por momentos nos permite digerir y situarnos de una manera menos paralizante ante esa realidad, pero a la vez borra no solo el contexto de producción de esas imágenes, sino también parte de la información que proporcionan.

\section{La imagen fotográfica en los límites}

En cuanto a la utilización de la imagen fotográfica para comunicar este tipos de hechos, teóricos de la memoria, la historia y el arte establecen unas reglas y cuidados de por sí particulares. De la imagen fotográfica se ha dicho que es un instrumento de crítica social, sensibilizadora, generadora de conciencia y verdadera (posturas tomadas por Gisele Freund, Roland Barthes, entre otros), pero también sensacionalista, cruda, violatoria y paralizante (reflexiones realizadas por Susan Sontag, entre otros); por su potencialidad y usos es claro que se maneja dentro de límites imprecisos, que aún son foco de múltiples controversias. Una de las características que posee la fotografía, según Baer, es su carácter espectacular, ya que la fotografía al ser índice de verdad, se encuentra en la disyuntiva entre la verdad histórica y la ética de la mirada o la forma adecuada de mostrar la memoria. Cuestiones que nos permite pensar esta muestra, que por un lado plantea la exhibición de lo sucedido, pero a la vez se queda a medio camino al no mostrar huellas de la tragedia, generando un efecto de sentido orientado al homenaje más que indicios al relato histórico.

También se da otra relación incómoda, ya que como explica Soulanges la fotografía nunca deja de ser una relación de a dos, de un sujeto que fotografía y de un sujeto que es fotografiado, es por eso que se instala la cuestión de por quién fueron sacadas las fotografías y en qué condiciones, aquí entra en juego la relación entre víctima y victimario; es decir, de quién es la mirada que toma la foto y desde qué lugar ideológico o moral mira al sujeto fotografiado. Aquí se da un dilema de perspectivas, ya que quien mira las fotografías se pone en la posición del victimario, en el mismo ángulo en que se realizaron las fotos. Para el caso de las fotografías del Holocausto Baer advierte que "al mostrar estas imágenes se corre por lo tanto el peligro de reproducir en cierta medida el acto obsceno de su producción, y de algún modo, el crimen del fotógrafo se convierte en el del espectador" (Op. Cit. Baer. p. 171). Es decir que se da un desfasaje sustancial entre las condiciones de producción de las imágenes y su recepción. Esta cuestión se reaviva y cobra sentido en la actualidad con las fotografías extraídas de la ESMA por Victor Basterra, ya que las fotos de los desaparecidos que logró rescatar fueron tomadas por los secuestradores, es decir que en esa imagen, no solo vemos víctimas sino que inexorablemente las vemos desde la perspectiva del verdugo. Más allá del lugar documental que tienen las imágenes, en este punto revivimos la mirada del secuestrador. No sucede lo mismo con los retratos de los militares que fueron tomados y recolectados por Basterra, ya que fueron sacadas por él mismo, a sus perpetradores; en condiciones extremas y bajo amenaza de muerte. 


\section{Conclusiones}

A modo de conclusión nos gustaría pensar sobre una frase de Susan Sontag que dice que "se puede sentir una obligación de mirar fotografías que registren grandes crueldades y crímenes. Se debería sentir la obligación de pensar en lo que implica mirarlas, en una capacidad efectiva de asimilar lo que muestran"(Op. Cit. Sontag. p. 111). Y es bajo esa idea que hemos planteado estas reflexiones, que tantas aristas y complicaciones presenta, no solo porque pone a prueba nuestra manera de mirar y cuestionar cómo y qué vemos, sino porque instala interrogantes, tensiones y dificultades.

Recuperando algunos de los puntos que hicieron eje a este análisis nos parece importante partir de la idea de que las decisiones estéticas y de montaje que tomó el museo, fueron una manera de acercarnos al material fotográfico y desde allí comenzar nuestra interpretación. Como hemos notado aún queda mucho por pensar sobre las fotografías rescatadas por Bastrerra, nos parece interesante la respuesta del MAM a ese imperativo que hizo sacar las fotos de la ESMA, y que continúa siendo dar testimonio, contar, revelar lo que allí sucedía. Estas imágenes conviven en difusos límites entre el registro y la evocación, ya que en tanto imágenes fotográficas contienen huellas de realidad y a su vez nos permiten evocar un recuerdo y construir una historia, las decisiones en el encuadre responden no sólo a una decisión discursiva sino también a un momento desde el presente, son imágenes que son interrogadas desde las preguntas del presente, desde ese 2007, año en que se retomaban los juicios de lesa humanidad y la necesidad de saber quién era quién era imperiosa. Y dentro de ese momento de la historia argentina nace este abordaje donde se trabaja una idea de sala-homenaje en contraposición a otra sala-escrache. Es un abordaje que nos otorga cierto tipo de información, y a su vez deja sin decir otro tanto; sobre todo en referencia a las condiciones de cautiverio de los desaparecidos y sobre la realidad vivida en la ESMA por esas personas. Transita el lugar de lo documental y a su vez lo artístico, brinda información y emoción, y a su vez habla de la pérdida y de la conservación de un registro y de una historia. Y sobre todo trabaja la relación de la elaboración y creación de discursos sobre el pasado traumático desde el presente. Es por eso que observamos el rol activo del MAM en la elaboración e instalación de esta temática para la comunidad y en un momento coyuntural. Como vimos, los diferentes encuadres responden a diferentes necesidades y usos de la imagen fotográfica.

Fue un delicado proceso pensar cómo montar ese material cuando aún nadie lo había hecho. Y creemos que existen otras maneras de interrogar y construir ese material, ya que las preguntas van cambiando a lo largo del tiempo. Creemos que otros de los abordajes posibles puede nacer de la pregunta por la historicidad del objeto que se muestra, en este caso imágenes fotográficas de militares y de desaparecidos en situación de encierro. A su vez tal vez sea posible pensar más sobre las relaciones y tensiones que existieron entre esos dos grupos, trascendiendo la dualidad y pensando en una muestra ni homenaje ni escrache, en un espacio tal vez más reflexivo o pensativo, complejizando y profundizando la información que aportan las imágenes. A su vez sería interesante pensar desde otro lugar la cuestión de la estética con este tipo de fotografías, que generan emociones y percepciones encontradas. 
La cuestión continúa siendo ¿Cómo mostrar éstas imágenes del centro clandestino de detención que funcionaba en la E.S.M.A.? , ¿Cómo transmitir la información y los mensajes que nos da este material?, ¿Desde dónde y cuándo interrogamos ese material?, ¿Cómo mostrar esas dos historias que conviven: la de ese acto de resistencia protagonizado por Victor Basterra de rescatar las fotos de la ESMA, y lo que relatan los propios retratos de los desaparecidos y los represores en la ESMA?

\section{Notas}

1. Agradezco la lectura atenta del primer borrador de este artículo a Claudia Feld, Elizabeth Jelin y Ludmila Catela da Silva.

2. Francois Soulages califica como "sin arte" a una realidad o cosa que es realizada sin un proyecto ni una voluntad artística. Soulages, F. (2010) Estética de la fotografía. Ediciones La Marca. Buenos Aires. Argentina.

3. Didi- Huberman, G. (2004) "Imágenes pese a todo. Memoria visual del Holocausto" Relata y analiza otro acto de resistencia que implicó sacar imágenes fotográficas de un campo de detención y exterminio Nazi. Se trataron de cuatro fotografías sacadas por miembros del Sonderkomando al crematorio V de Auschwitz con el objetivo de dar testimonio de lo que allí sucedía, ya que víctimas de los campos, arriesgaron su vida para sacar y dejar una huella que lo muestre. También se trató de un acto de resistencia y con la perspectiva de denunciar lo que allí sucedía. Pese a los puntos en común que puede haber entre estos dos sucesos no los analizaremos comparativamente, ya que hay especificidades e historiografías muy diferentes.

4. Es recién en el año 2009 que es editado un libro sobre estas imágenes, se trata de : E.S.M.A. (2009) ARCHIVOS DE LA ESMA. La Plata. Editorial De la Campana, 156 págs. Al momento de la muestra aún no había textos específicos sobre esta temática y aún hoy es muy poco el material académico publicado sobre estas fotografías y su historia.

5. Id. Ibid. Barthes, R. Pág. 67: “El studium es contrato filmado entre creadores y consumidores. El studium es una especie de educación (saber y cortesía) que me permite encontrar al Operator (el fotógrafo), vivir las miras que fundamentan y animan sus prácticas, pero vivirlas en cierto modo al revés, según mi querer de Spectator".

6. Otro de los puntos que consolidan el relato fueron las visitas guiadas que se hicieron, sobre todo con grupos escolares. Allí a través de la palabra se transmite y se afirma la historia de esas imágenes, comentan las curadoras. Cuestiones que no hemos abordado en este texto ya que no realizamos el trabajo de campo en ese momento y no hay registro de esa actividad. 


\section{Referencias Bibliográficas}

Baer, A. (2006). Holocausto. Recuerdo y representación. Madrid: Ed. Losada.

Barthes, R. (1994). La cámara lúcida. Nota sobre la fotografía. Barcelona: Ediciones Paidós.

Brodsky. M. (2005). Memoria en construcción. El debate sobre la ESMA. Buenos Aires: Editorial La Marca.

Carras, R. (2009). Pensamientos, prácticas y acciones del GAC. Buenos Aires: Editorial Tanta Limón.

Catela da Silva, L. (2009). Lo invisible revelado. El uso de fotografías como (re) presentación de la desaparición de personas en Argentina. En Feld, C. y Stites Mor, J. Comps. El pasado que miramos. Buenos Aires: Editorial Paidós. pp. 337- 363.

(2001). No habrá flores en la tumba del pasado. La experiencia de la reconstrucción del mundo de los familiares de desaparecidos. La Plata: Ediciones Al Margen.

Cueto Rúa, S. (2010). Demandas de justicia y escrache en HIJOS La Plata. Trabajos y Comunicaciones, 2da. Época, no 36. Departamento de Historia. Facultad de Humanidades y Ciencias de la Educación. Universidad Nacional de La Plata. pp. 165-183.

Damisch, H. (2007). El desnivel: la fotografía puesta a prueba. Buenos Aires: Editorial La Marca.

Didi-Huberman, G. (2004). Imágenes pese a todo. Memoria visual del Holocausto. Barcelona: Ediciones Paidós Ibérica S.A.

Edwards, E. (2001). Replantear la fotografía en el museo etnográfico. En Naranjo, J. Ed. Fotografía, antropología y colonialismo (1845- 2006). (2006). Barcelona: Editorial Gustavo Gili, SL.

El hombre que retrató a los represores argentinos. (13/01/2010). El Mundo. España.

El que "sacó" las fotos. (20/11/2009). Página 12.

E.S.M.A. (2009). ARCHIVOS DE LA ESMA. La Plata: Editorial De la Campana, 156 págs.

Feld, C. (2012). Image et récit dans le témoignage de Víctor Basterra, survivant de l'ESMA, en Fleury, B. y Walter, J. (dirs.). Les devenirs-témoins de conflits du XXe siècle (1) Le témoin itératif. Nancy: Presses universitaires de Nancy (en presse).

Folleto de la muestra Rostros. Fotos sacadas de la ESMA. (Marzo de 2007). Museo de Arte y Memoria. La Plata.

Friedlander, S. (2007). En torno a los límites de la representación. El Nazismo y la solución final. Quilmes: Editora Universidad Nacional de Quilmes.

García, L. I y Longoni A. (2012). Imágenes invisibles. Acerca de las fotos de desaparecidos. Revista Sala Grumo, pp. 9-21. Número 9. Brasil: Editorial Sala Grumo S. A. Disponible en: www.salagrumo.org

Instituto Espacio para La Memoria. Entrevista a Víctor Basterra "Robarle la identidad a los milicos”. (s/f). Argentina. Disponible en http://www.institutomemoria.org.ar/.

La Camiseta. (1/11/2011). Página 12.

Lemagny, J.-C. (2008). La sombra y el tiempo. La fotografía como arte. Buenos Aires: Editorial La Marca. 
Narrar la ESMA. (20/11/2005). Página 12.

Publicación del Centro de Estudios y Legales (CELS). (1984). Testimonio sobre el Centro Clandestino de Detención de la Escuela de Mecánica de la Armada (ESMA). Buenos Aires.

Revista La Voz de la Juventud Peronista, Regional 1, agosto de 1984. pp. 11- 15.

Sontag, S. (1993). Ante el dolor de los demás. México: Editorial Alfaguara.

Soulages, F. (2010). Estética de la fotografía. Buenos Aires: Ediciones La Marca.

\section{Entrevistas}

Laura Ponicio. Actual directora del Museo de Arte y Memoria de La Plata, curadora de la Muestra "Rostros. Fotos sacadas de la ESMA". Elaboración propia. 27 de abril de 2012. Julia Alba. Actual curadora en el Museo de Arte y memoria de La Plata, curadora de la muestra "Rostros. Fotos sacadas de la ESMA". Elaboración propia. 23 de abril de 2012.

Paula Bonomi. Actual empleada en la Comisión Provincial por la Memoria de la Pcia. de Buenos Aires (CPM) en el área de Comunicación y Cultura, redefinida en el año 2012 como Área de Comunicación y Prensa. Empleada en el área de Prensa y Comunicación de la CPM en el momento de la muestra dependiente del Museo de Arte y Memoria. Elaboración propia. 7 de mayo de 2012.

Ana Caccopardo. Directora del MAM durante el período 2002- 2012.Elaboración propia. 9 de agosto de 2012. 


\section{Catálogo de Figuras}

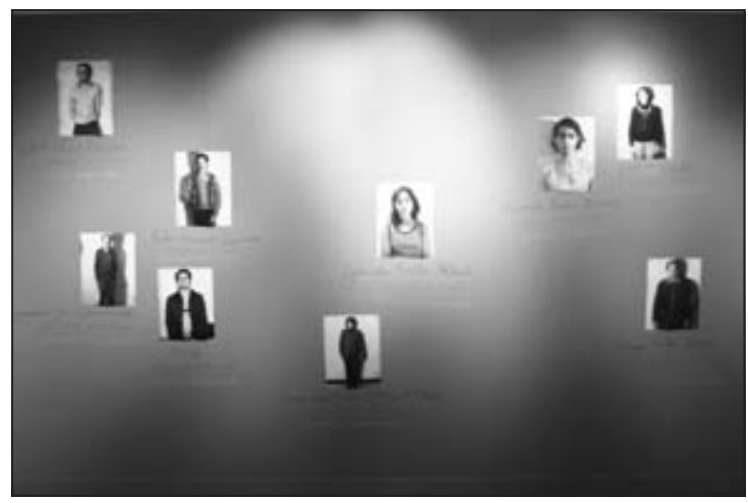

F1.

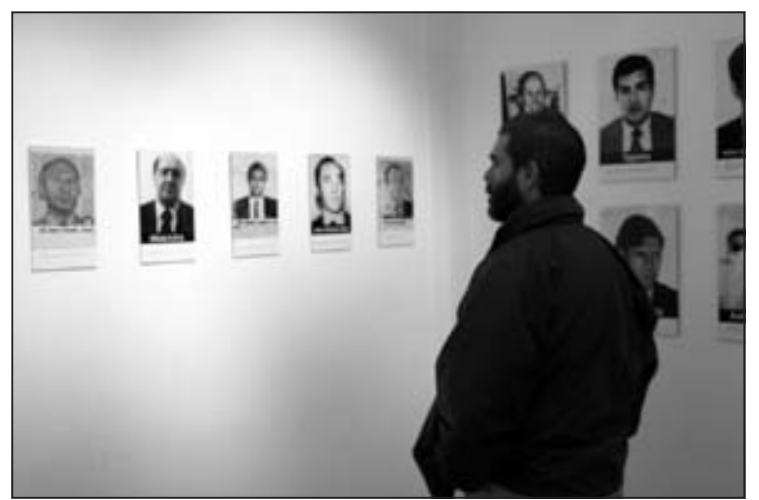

F2.

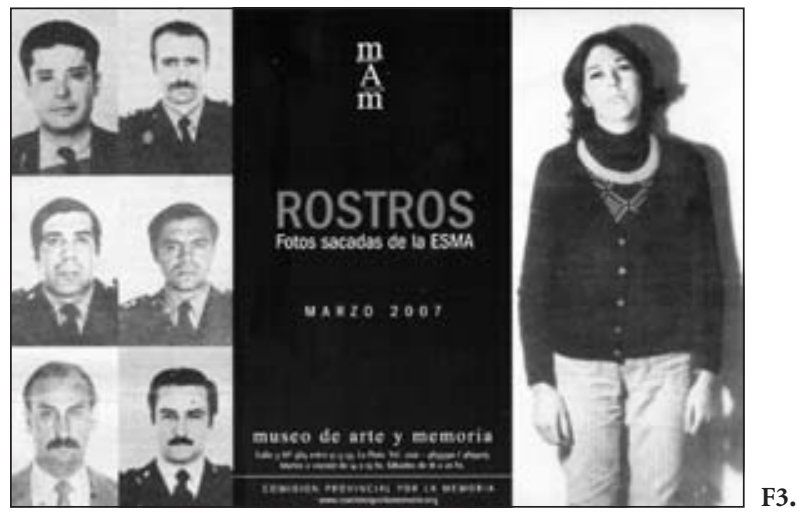



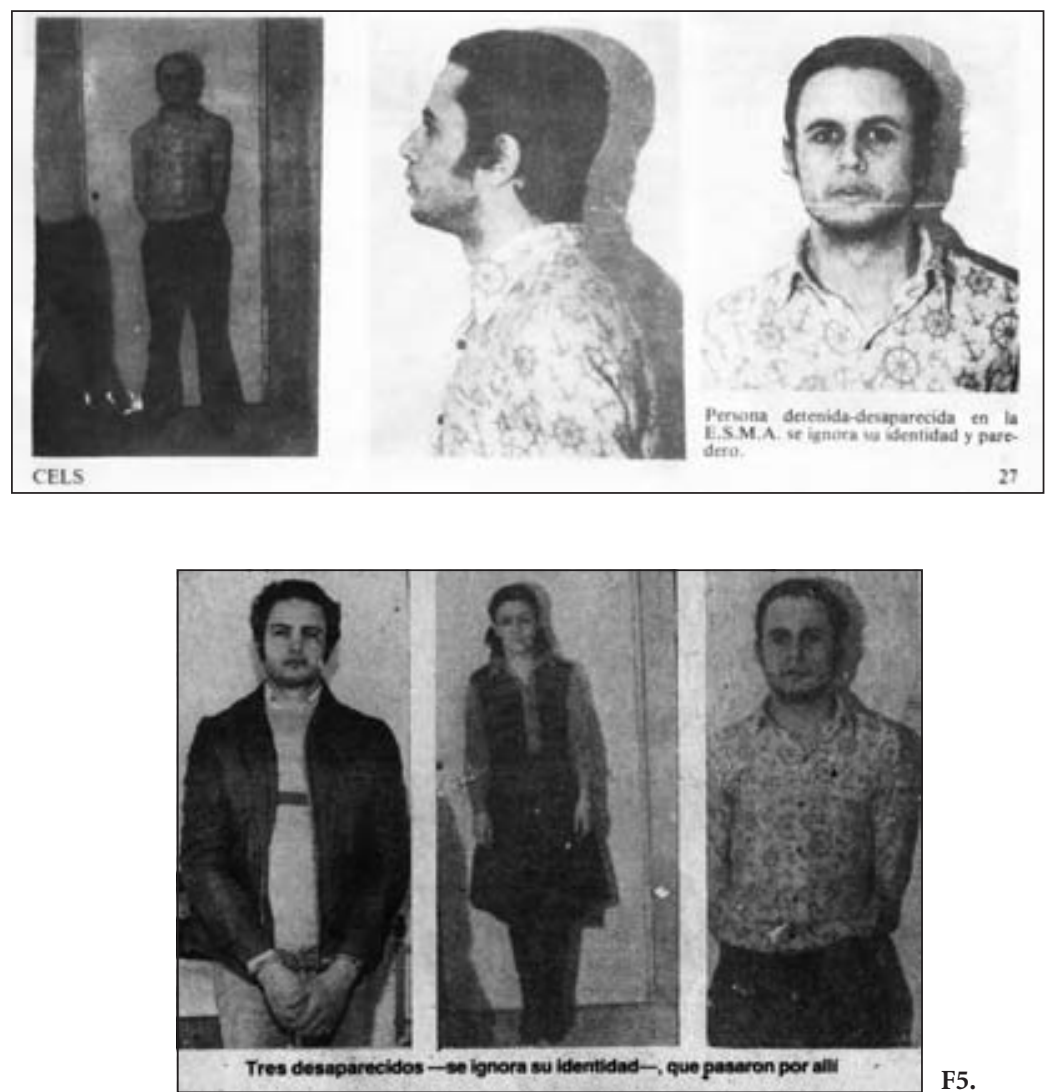

F5.
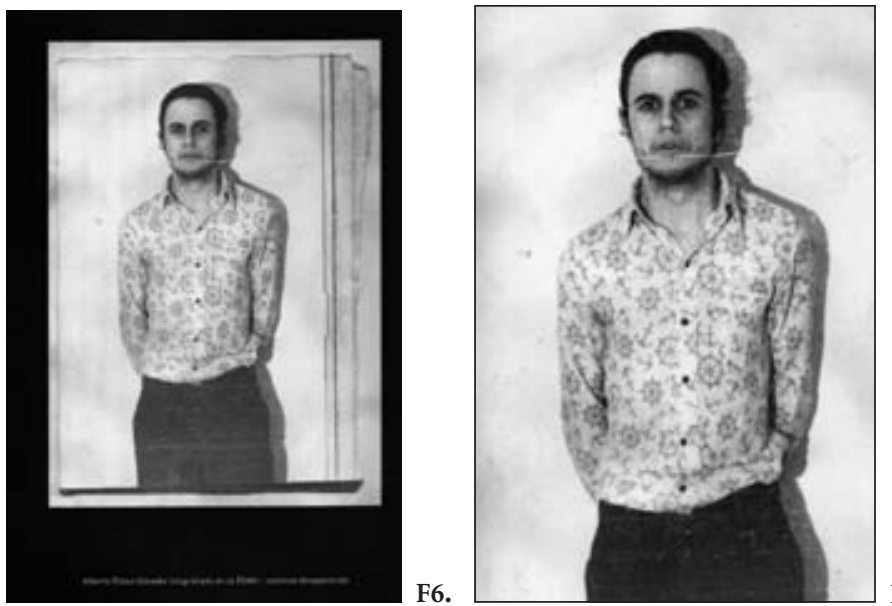

F7. 


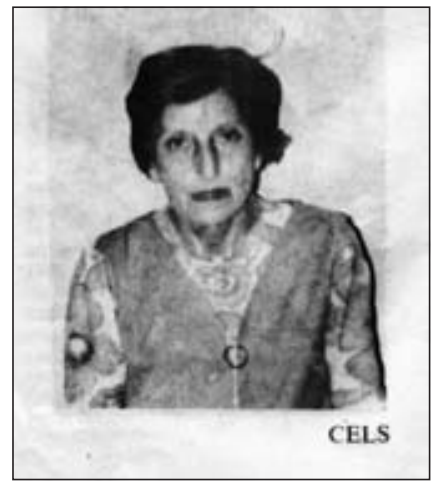

F8.

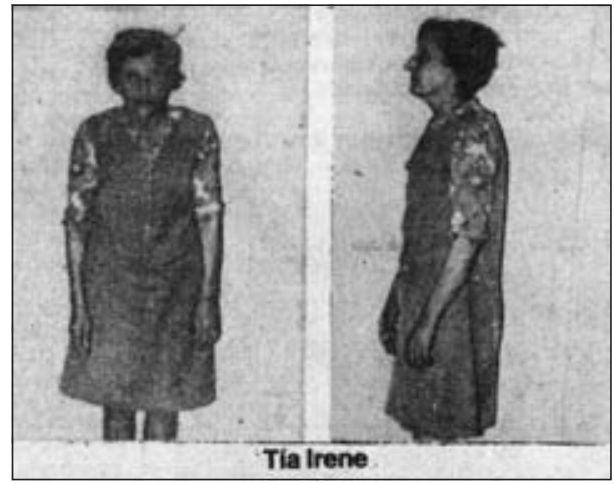

F9.
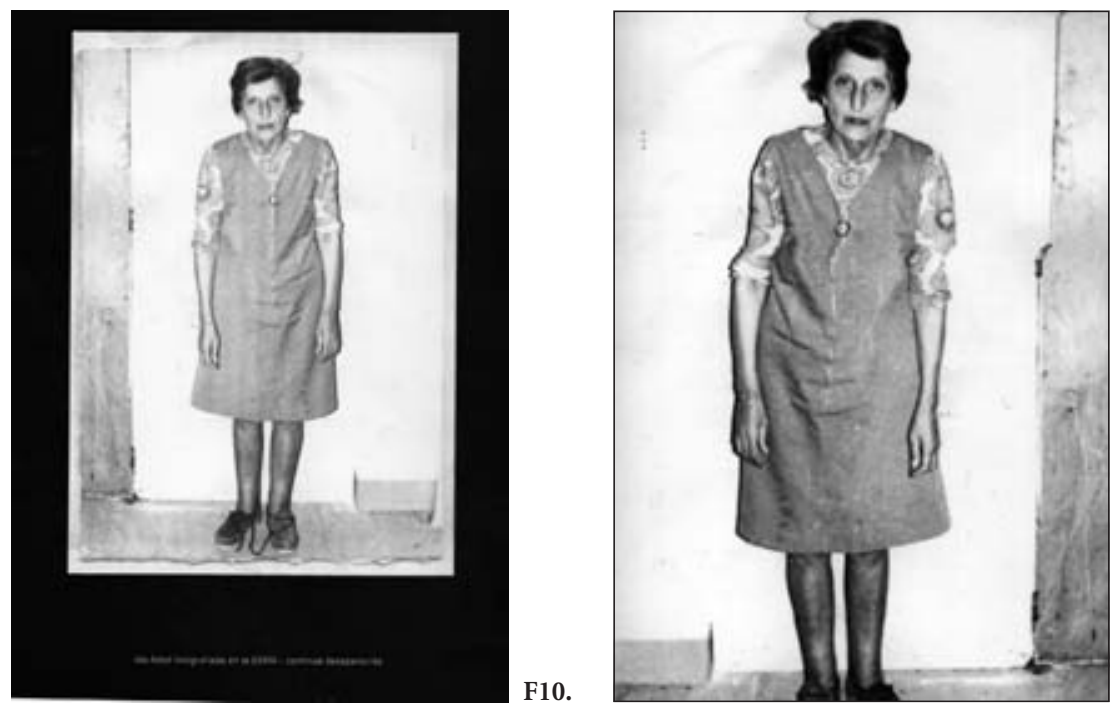

F11. 

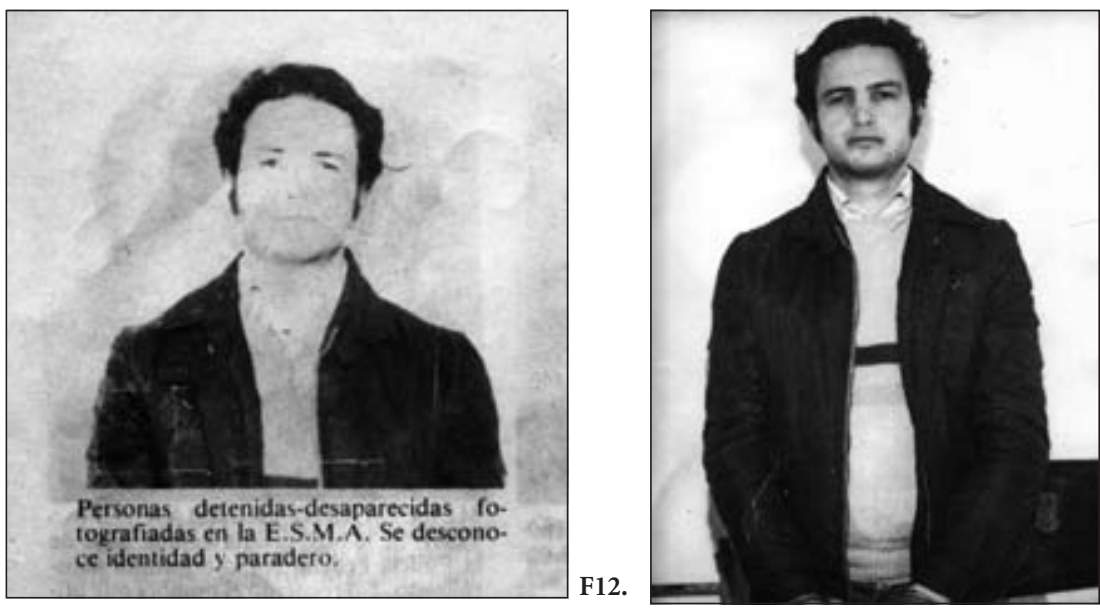

F13.

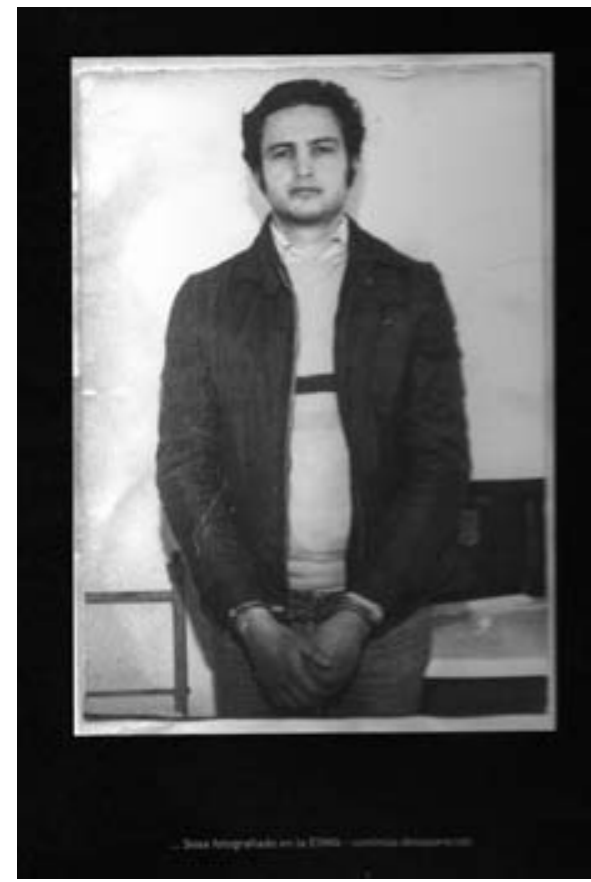

F14. 
Figura 1. Sala de los desaparecidos. Fuente. Florencia Larralde Armas. Figura 2. Sala de los represores. Fuente. Florencia Larralde Armas. Figura 3. Folleto MAM, 2007. Fuente. Florencia Larralde Armas.

Figura 4. Imagen de Alberto Eliseo Donadio. Fuente. Publicación del CELS. p. 27. Octubre de 1984. Figura 5. Retratos de Sosa, Elsa y Donadio. Fuente. Revista de la JP. p. 13. Agosto de 1984.

Figura 6. Imagen de Alberto Eliseo Donadio. Fuente. Memoria en Construcción de Marcelo Brodsky, 2005.

Figura 7. Imagen de Alberto Eliseo Donadio expuesta por el MAM. Fuente. MAM, 2007.

Figura 8. Ida Adad. Fuente. Publicación del CELS. Octubre de 1984.

Figura 9. Ida Adad, “Tía Irene”. Fuente. Revista de la JP. Agosto de 1984.

Figura 10. Ida Adad. Fuente. Memoria en Construcción, de Marcelo Brodsky, 2005.

Figura 11. Retrato de Ida Adad expuesto el MAM. Fuente. MAM, 2007.

Figura 12. Imagen de Sosa. Fuente. Documento del CELS. Octubre de 1984.

Figura 13. Foto de Sosa. Fuente. Memoria en Construcción de Marcelo Brodsky, 2005.

Figura 14. Retrato de Sosa. Fuente. MAM, 2007.

Summary: Faces, pictures from the ESMA was the title of the exhibition led by the Museum of Art and Memory (MAM ) of La Plata, in March 2007 This was an exhibition of photographs rescued by Victor Basterra from that clandestine detention center where he was for over four years, abducted and forced into slave labor during the last military dictatorship in Argentina. These images were shown for the first time in a memorial space and artistic exhibition at that time. This article will investigate how these images enter into an artistic space. We will reflect on the movement, editing and assembly operations to which these images were submitted by the MAM. This exhibition challenges us to wonder about tensions inherent in the photographic image; as they are between the loss and conservation; registration and recall, documentary and artistic; information and emotion, past and present.

Key words: Argentina - Art - clandestine detention center - conservatorship - dictatorship - displacement - document - memory - museum - photography.

Resumo: Rostros, fotos sacadas de la ESMA foi o título que levou a mostra montada por o Museu de Arte e Memória (MAM) de La Plata, em março de 2007. Foi uma exposição das fotografias resgatadas por Victor Basterra do centro clandestino de detenção onde esteve mais de quatro anos, seqüestrado e forçado a fazer trabalhos escravo durante a última ditadura militar na Argentina. Estas imagens se exibiram pela primeira nessa ocasião num espaço de exibição memorial e artístico. Neste artigo se examinarão como essas imagens ingressam a um espaço que admite que sua linguagem e a arte. Reflexionar-se-á sobre os deslocamentos, operações de edição e montagem às que estas imagens foram submetidas por o MAM. Esta mostra nos interpela sobre tensões próprias da imagem fotográfica, porque se encontram entre a perda e a conservação; o registro e a evocação, o documental e o artístico; a informação e a emoção, o passado e o presente.

Palavras chave: Argentina - arte - centro clandestino de detenção - curadoria - deslocamentos - ditadura - documento - fotografia - memória - museu. 